\title{
Regional Ecological Network Planning for Biodiversity Conservation: A Case Study of China's Poyang Lake Eco-Economic Region
}

\author{
Haiou Yang ${ }^{1,2,3}$, Wenbo Chen ${ }^{2 *}$, Xiaoping Chen ${ }^{2}$ \\ ${ }^{1}$ College of Forestry, Jiangxi Agricultural University, Nanchang 330045, China \\ ${ }^{2}$ Key Laboratory of Landscape and Environment, Jiangxi Agricultural University, Nanchang 330045, China \\ ${ }^{3}$ College of Tourism and Territorial Resources, Jiujiang University, Jiujiang 332005, China
}

Received: 19 October 2016

Accepted: 8 February 2017

\begin{abstract}
Ecological networks have been considered to be an effective strategy to counter habitat fragmentation, which is occurring in the urbanization context. Researchers and planners have begun to integrate ecological networks in both thematic planning and urban or regional planning for biodiversity conservation and sustainable development. In this paper, we integrated the least-cost path model, network structure analysis, and gravity model to construct a regional ecological network of Poyang Lake Eco-economic Region, China. The least-cost model was improved by integrating three resistance factors, including land cover, slope, and human-induced pressure into it, presenting the landscape characteristics comprehensively in corridor simulation. The network structure analysis was employed to assess the proposed ecological network and the gravity model was used to identify the relative significance of network elements. Results indicated that the proposed hierarchical ecological network has good circuitry, complexity, and connectivity. Spatial analysis of prioritized network elements and breaking points revealed the regional connectivity condition, presenting significant reference to decision making in both land-use management and network implementation. Our study demonstrated that the integrated methodology is effective in regional ecological network planning and shows feasibility to be applied to other regions.
\end{abstract}

Keywords: ecological network, biodiversity conservation, least-cost path model, network structure analysis, gravity model

\section{Introduction}

Evidence shows that the earth's sixth massive species extinction has already arrived and the extinction rates of birds and mammals may be 100 to 1,000 times that found in undisturbed nature, greater than any time in the past few

*e-mail: cwb1974@126.com centuries [1-2]. Habitat fragmentation, loss, and isolation occurring in the urbanization context are commonly considered the main causes of the species extinction crisis [3-5]. Ecologists and biologists recommend strengthening the connectivity between fragmented habitats to create a coherent large-scale ecosystem as a solution to enable threatened species to survive [6-7]. Habitat connectivity plays an important role in population viability because it ensures gene flow and facilitates migration, dispersal, 
and re-colonization [8]. Thus, ecological networks, with the function of strengthening connectivity among habitat patches, are increasingly being used to meet the needs of biodiversity conservation [9-11].

The concept of ecological networks was developed by landscape planners in Europe and North America in the 20th century to solve the conflicts between the urban sprawl and biodiversity conservation [12-14]. An ecological network is constituted by ecological components, including core areas, corridors and buffer zones, which provide the physical conditions necessary for ecosystems and species populations to survive in a humandominated landscape [15]. Currently, ecological networks have been developed not only in thematic planning, e.g., forest, urban green space, and wetland planning, but also in comprehensive urban, regional, and landscapescale planning [16-21]. Ecological networks are mainly constructed or evaluated by three kinds of methods: (a) suitability analyses, (b) structural indices methods, and (c) ecological process-based methods [19]. As suitability analyses and structural indices methods don't consider the complex ecological processes, ecological processbased methods are increasingly used in ecological networks planning [19, 22-23]. The least-cost path model, an ecological process-based method, is a prime choice to develop ecological networks. However, some scholars often choose land cover as the only resistance factor of least-cost path model as it is complex to include more precise landscape characteristics [17, 19, 24-25]. Nonetheless, more scholars regard environmental factors, e.g., height and slope, and human disturbance should also be considered in developing ecological networks as they can significantly affect the dispersal movements of animals [26-28].

Poyang Lake Eco-Economic Region, located in northern Jiangxi Province, possesses a wide biodiversity for its abundant habitat resources. It is an experimental region of China's national strategies aimed at the win-win of economic growth and ecological protection. Like many other regions in China, numerous ecological lands in Poyang Lake Eco-Economic Region have been converted to built-up areas for supporting the rapid industrialization and urbanization process. According to statistics, the number of increased built-up areas from 2005 to 2010 was $454.4 \mathrm{~km}^{2}$, at an annual increase rate of $8.92 \%$. As a result, increased habitat loss and fragmentation in the region have become great threats to biodiversity maintenance. In this region, increasing natural areas to conserve biodiversity may no longer be realistic as it relies more on financial and resource advantages rather than ecological function. Instead, developing an ecological network is a suitable strategy since no ecological networks have been designed for this region so far. From the perspective of landscape ecology, a regional-scale ecological network's significance lies in the fact that it can increase the connectivity of fragmented habitat patches to the widest extent, making fragmented patches return to the landscape matrix and thus forming a functionally coherent largescale ecosystem.
In this paper, we selected Poyang Lake Eco-economic Region as the study area to construct a regional ecological network. The specific objectives of this study were: 1) to establish a "point-line-plane" ecological network of the Poyang Lake Eco-Economic Region and 2) to prioritize the elements of the proposed ecological network and identify the breaking points for improving biodiversity conservation. Mammals were used as focal species for the design of the ecological network because: 1) the areas and corridors that they require can also be used by multiple other species and 2) they are particularly sensitive to the barrier effect caused by roads [29-30]. Three resistance factors, including land cover, slope, and human-induced pressure, were incorporated into the least-cost path model to simulate the corridors. The network structure analysis was applied to assess the proposed ecological network and the gravity model was used to identify the relative significance of the network elements.

\section{Materials and Methods}

\section{Study Area}

The Poyang Lake Eco-Economic Region $\left(28^{\circ} 30^{\prime} \mathrm{N}-30^{\circ} 06^{\prime} \mathrm{N}, 114^{\circ} 29^{\prime} \mathrm{E}-117^{\circ} 25^{\prime} \mathrm{E}\right)$, one of the most rapidly growing economic areas in southern China, is located on the south bank of the Yangtze River's middleand-lower reaches in northern Jiangxi Province. It includes 38 administrative counties and covers approximately $51,200 \mathrm{~km}^{2}$. It is surrounded by mountains and five rivers (Gan, Fu, Xin, Rao, and Xiu), which flow into Poyang Lake and then converge into the Yangtze (Fig. 1). The region belongs to the subtropical humid climate zone; its average annual temperature ranges from 16 to $18^{\circ} \mathrm{C}$, and annual precipitation is about $1,600 \mathrm{~mm}$. Poyang Lake Eco-economic Region is a significant region for ecological protection since Poyang Lake is one of the six wetlands with the richest biodiversity in the world [31]. In order to protect the environment and biodiversity, a land-use policy named "returning arable land to natural habitat" has been practiced since 1999 [32]. In addition, 11 national or provincial nature reserves had been established by the end of 2011.

\section{Date Sources}

We obtained the land use data in 2012 with a scale of 1:10,000 from the Department of Land Resources of Jiangxi Province. Data were reclassified into 10 land cover types: forest, wetland, farmland, garden, grassland, water body, urban land, village, traffic land, and other. The builtup areas were extracted from the land use data to evaluate human-induced pressure. A digital elevation model (DEM) with a spatial resolution of $30 \mathrm{~m}$ was obtained from the International Scientific Data Service Platform (http:// datamirror.csdb.cn/), and the slope data were generated with the DEM. Three factors - land cover, slope and human-induced pressure - were used as resistance factors 
in cost surface of the least-cost path model. The nature reserves distribution data for 2012 were used in source selection, which were collected from the Department of Forestry of Jiangxi Province. The traffic data for 2012 were used to identify breaking points of the proposed ecological network, and were obtained from the Traffic Department of Jiangxi Province. All data were converted to a geo-database and processed using ArcGIS 9.3 with the Beijing54 coordinate system.

\section{Simulation of Potential Corridors Based on Improved Least-cost Path Model}

Originating from graph theory, the least-cost path model is based on effective distance, which is a straightforward way to include the detailed geographical information on the landscape as well as behavioral aspects of organisms into models [29, 33-34]. The least-cost path model needs two inputs: a cost surface layer and a source layer. Then the eight-neighboring-cell algorithm computes the route with minimum cost that connects pairs of habitat patches.

Sources inputs are the origins of the dispersal and maintenance of species, which are internal, homogeneous, and have the characteristic of expanding around or being the "sources" for themselves [33]. The sources are representative areas of high ecological value, and can fully reflect the habitat requirements of the protected species [35]. When choosing sources, the following factors were considered: 1) the patch area, 2) the importance of biodiversity conservation, and 3) spatial distribution. Cost indicates the resistance value, geographic position, and orientation of all relevant landscape elements [30]. In general, the least-cost path model considers only one factor [25]. In this paper, we combined land cover, slope, and human-induced pressure as a comprehensive cost surface to improve the least-cost path model. Weights for land cover factor, slope, and human-induced pressure were assigned $0.4,0.3$, and 0.3 , respectively, according to expert knowledge. The resistance values of three cost surfaces for the focal species were assigned through bibliographical review [16-17, 19, 29] and expert consultation. The resistance values range from 1 to 1,000, with higher values indicating higher resistance. Weighted-accumulative cost surfaces and corresponding backlink direction surfaces for each source were generated using batch commands of cost distance tools. Then the least-cost paths between pairs of sources were generated.

\section{Analysis of Ecological Network}

Network circuitry index $\alpha$ is expressed as follows: network structure analysis introduces a process for aggregating results of patch and corridor analysis, then incorporates indicators that describe interrelationships between landscape elements [36]. Based on graph theory, it simplifies a landscape into a set of nodes (habitat areas), whose functionally is connected to some degree by corridors that join pairs of nodes [30]. The number, length, and density of corridors were used to describe their structural characteristics [37]. Indices of $\alpha, \beta$, and $\gamma$ represent network circuitry, node-to-corridor ratio, and network connectivity, respectively. These three indices are used to evaluate the significance and complexity of the ecological network [36].

Network circuitry index $\alpha$ is expressed as follows:

$$
\alpha=\frac{l-v+1}{2 v-5}
$$

...where $l$ is the number of linkages and $v$ is the number of nodes. This $\alpha$ index represents the ratio of the network formed by loops and ranges from 0 to 1 . The higher the

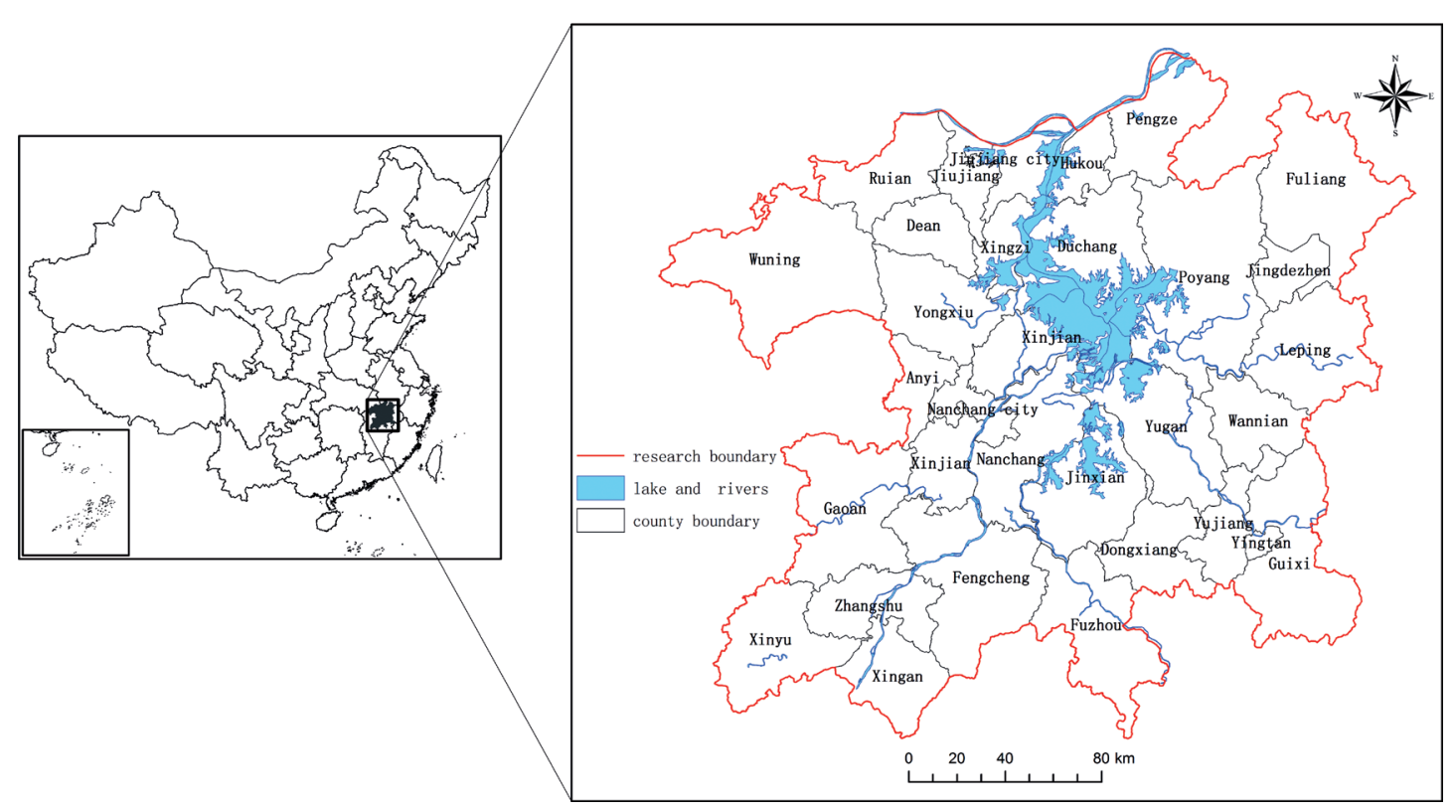

Fig. 1. Location of Poyang Lake Eco-Economic Region. 
value of $\alpha$, the more diffusion paths can be chosen by creatures when going across the network [36]. If $\alpha$ is 0 , then there is no loop in the network. If $\alpha$ is 1 , the number of loops in the network is maximized [37].

Node-to-corridor ratio $\beta$ represents the number of linkages divided by the number of nodes, and is expressed as follows:

$$
\beta=l / v
$$

...where $l$ is the number of linkages and $v$ is the number of nodes, as above. When $\beta$ is smaller than 1 , the ecological network is a dendrogram; when $\beta$ is 1 , the ecological network is a single loop; and when $\beta$ is bigger than 1 , the ecological network reaches a complex level [38].

Network connectivity $\gamma$ represents the ratio of the actual number and maximum possible number of linkages in a network:

$$
\gamma=\frac{l}{l_{\max }}=\frac{l}{3(v-2)}
$$

... where the $\gamma$ index varies between 0 and 1 and $l_{\max }$ is the maximum possible number of linkages. When $\gamma$ is 0 , all the nodes are independent and linked to no others; when $\gamma$ is 1 , all the nodes are linked to others [38].

\section{Prioritization of Network Elements Based on Gravity Model}

The least-cost path model can be employed to identify the route that has the least resistance value between two sources, but it provides little information about the relative ecological importance of corridors when the connections are developed from one source to many others $[17,38]$. The problem can be solved with the gravity model [38], which is the most common method for assessing the interaction between pairs of nodes [17]. In general, the greater the interaction, the more effective the corridor [17].

Connectivity using the gravity model is determined as follows:

$$
G_{a b}=\frac{N_{a} N_{b}}{D_{a b}^{2}}
$$

$\ldots$ where $G_{a b}$ is the interaction between nodes $a$ and $b$, $N_{a}$ and $N_{b}$ are their corresponding weights, and $D_{a b}$ is the normalized cumulative resistance value of the corridor between nodes $a$ and $b$. In general, the interactions between areas are greater when they are larger and closer [38]. The node weights are defined by the weighted resistance value [17]:

$$
N_{i}=\frac{1}{P_{i}} \times \ln \left(S_{i}\right)
$$

... where $N_{i}$ is the weight, $P_{i}$ the resistance value of patch $i$, and $S_{i}$ the normalized patch size of node $i$.

$D_{\mathrm{ab}}$ is defined as:

$$
D_{a b}=L_{a b} / L_{\max }
$$

... where $L_{a b}$ is the cumulative resistance value of corridor $L$ between nodes $a$ and $b$, and $L_{\max }$ is the maximum cumulative resistance value of all the potential corridors.

Then formula (4) can be expressed as follows:

$$
\begin{aligned}
G_{a b}=\frac{N_{a} N_{b}}{D_{a b}^{2}}= & \frac{\left[\frac{1}{P_{a}} \times \ln \left(S_{a}\right)\right]\left[\frac{1}{P_{b}} \times \ln \left(S_{b}\right)\right]}{\left[\frac{L_{a b}}{L_{\text {max }}}\right]}= \\
& =\frac{L_{\max }^{2} \ln \left(S_{a} S_{b}\right)}{L_{a b}^{2} P_{a} P_{b}}
\end{aligned}
$$

...where $S_{a}$ and $S_{\mathrm{b}}$ represent the normalized sizes of patches $a$ and $b$, and $P_{a}$ and $P_{b}$ represent the corresponding resistance value.

\section{Results}

\section{Construction and Analysis of the Ecological Network}

Resistance values of the considered three cost surfaces were assigned as Tables 1, 2, and 3. The comprehensive cost surface was obtained by overlaying the three weighted cost surfaces (Fig. 2). We identified 13 core habitat patches as sources (Fig. 3). The sources cover

Table 1. The resistance values of different land cover types.

\begin{tabular}{|c|c|c|}
\hline Resistance factor & Type & Value \\
\hline \multirow{7}{*}{ Land Cover } & Forest & 3 \\
\cline { 2 - 3 } & Wetland & 5 \\
\cline { 2 - 3 } & Farmland & 100 \\
\cline { 2 - 3 } & Garden & 30 \\
\cline { 2 - 3 } & Grassland & 30 \\
\cline { 2 - 3 } & Water body & 600 \\
\cline { 2 - 3 } & Urban land & 1,000 \\
\cline { 2 - 3 } & Village & 800 \\
\cline { 2 - 3 } & & Airport: 600 \\
\cline { 2 - 3 } & Traffic land & highway, railway: 500 \\
\cline { 3 - 4 } & & other roads: 200 \\
\cline { 2 - 3 } & Others & 700 \\
\hline
\end{tabular}


Table 2. The resistance values of different slopes.

\begin{tabular}{|c|c|c|c|}
\hline $\begin{array}{c}\text { Resistance } \\
\text { factor }\end{array}$ & Type & $\begin{array}{c}\text { Slope range } \\
\text { (in }\end{array}{ }^{\circ}$ ) & Value \\
\hline \multirow{4}{*}{ Slope } & Flat slope & $<5$ & 5 \\
\cline { 2 - 4 } & Gentle slope & $6-15$ & 20 \\
\cline { 2 - 4 } & Steep slope & $16-45$ & 70 \\
\cline { 2 - 4 } & Dangerous slope & $>45$ & 100 \\
\hline
\end{tabular}

Table 3. The resistance values of human-induced pressure.

\begin{tabular}{|c|c|c|c|}
\hline $\begin{array}{c}\text { Resistance } \\
\text { factor }\end{array}$ & Type & $\begin{array}{c}\text { Distance from built-up } \\
\text { area (in m ) }\end{array}$ & Value \\
\hline \multirow{4}{*}{$\begin{array}{c}\text { Human-induced } \\
\text { pressure }\end{array}$} & 1 & $0-1,000$ & 100 \\
\cline { 2 - 4 } & 2 & $1,000-3,000$ & 70 \\
\cline { 2 - 4 } & 4 & $3,000-5,000$ & 50 \\
\cline { 2 - 4 } & 5 & $5,000-7,000$ & 30 \\
\hline
\end{tabular}

an area of 5,776.02 $\mathrm{km}^{2}(11.28 \%$ of the study area). Based on the identified sources and cost surfaces, 78 corridors between each pair of sources were determined with the least-cost path model and 44 intersections of corridors were identified as nodes (Fig. 3). In this way, a "pointline-plane" ecological network of Poyang Lake EcoEconomic Region was established (Fig. 3). As Table 4 shows, the total length of the corridors is $2,232.99 \mathrm{~km}$ and the corridor density of the proposed network is $0.044 \mathrm{~km} /$ $\mathrm{km}^{2}$. The $\alpha$ index is 0.422 , reflecting that there are enough available loops in the region for wildlife movement. The $\beta$ index is 1.773 , indicating that the ecological network is complicated. The $\gamma$ index is 0.619 , meaning that the ecological network has a relatively high level of connectivity, which is as important as the sizes or numbers of nodes to maintain regional biodiversity.

\section{Priority Identification of Ecological Sources, Corridors, and Nodes}

In urban environments, there is usually one mother patch that has a significant influence on the surrounding area, which also applies to regional environments [39]. In this paper, two types of sources were recognized according to the $G$ values: mother sources and satellite sources. Mother source was defined as an ecological patch that has a greater influence over satellite sources than satellite sources have on it. The $\mathrm{G}$ values between the 13 sources vary from 2 to 1,091 (Table 5). The maximum $G$ value is between source 5 (Poyang Lake) and source 2
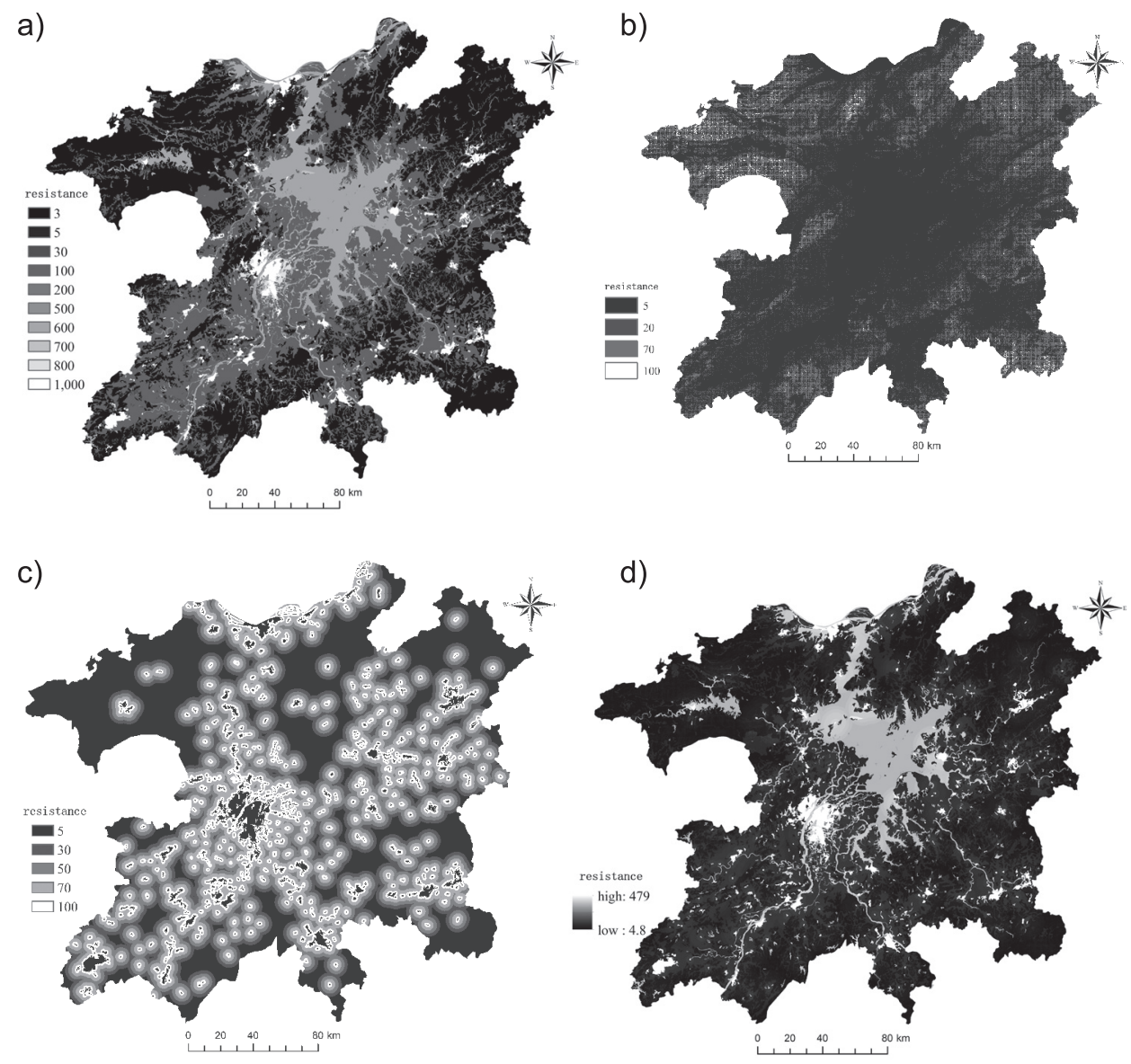

Fig. 2. a) land cover cost surface, b) slope cost surface, c) human-induced pressure cost surface, d) comprehensive cost surface. 


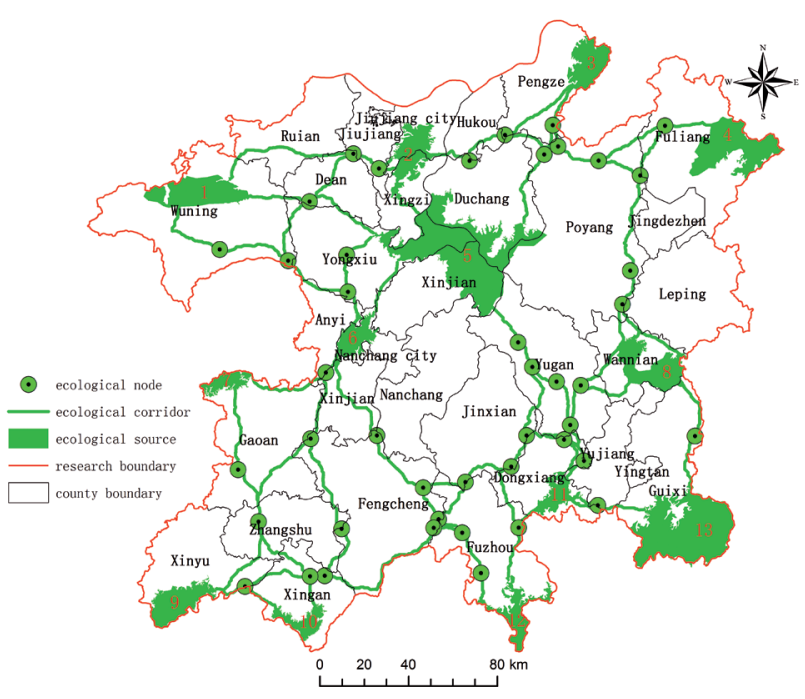

Fig. 3. The proposed "point-line-plane" ecological network.

(Lushan), suggesting that the corresponding corridor has the minimum accumulated resistance value and the highest frequency of organism movement, since the accumulated resistance is expected to be inversely proportional to the frequency of an organism's movement. The $G$ values between source 5 (Poyang Lake) and its surrounding sources - e.g., source 1 (Yishan), source 2 (Lushan), and source 3 (Taohongling Spotted Deer) - are also higher than that between others, so that source 5 (Poyang Lake) was identified as the mother source and others as satellite sources. The $\mathrm{G}$ value between sources 3 (Taohongling Spotted Deer) and source 9 (Xinyu Green-core) is the minimum, due to the long distance and the accumulated costs. The $\mathrm{G}$ values between source 6 (Meiling National Forest Park) and the southern ones (sources 8-13) are small, because Nanchang, the capital of Jiangxi Province, in the southwest of source 6 (Meiling National Forest Park), has greatly blocked species dispersal. While in the southwest, the interaction among sources (sources 7, 9, and 10), are also rather weak due to the farmland-donated land use pattern.

Ecological corridors are the main components of an ecological network, but their importance varies. We prioritized the corridors into three levels: corridors with $\mathrm{G}>100$ as level-one, $15<\mathrm{G}<100$ as level-two, and $\mathrm{G}<15$ as level-three corridors (Fig. 4). There are 10 level-one corridors with a total length of $685.05 \mathrm{~km}$, 16 level-two corridors with a total length of 912.66 $\mathrm{km}$, and 42 level-three corridors with a total length of $635.28 \mathrm{~km}$.

Ecological nodes in network were defined as the intersections between corridors. In this study, the ecological nodes were also divided into three levels according to the corresponding level of ecological corridors (Table 6). We identified 12 level-one ecological nodes, mainly distributed in the northern study area, 23 level-two ecological nodes distributed rather evenly in the study area, and nine level-three ecological nodes concentrated in the southwest (Fig. 4).

Table 4. The corridor structure metrics for the ecological network planning.

\begin{tabular}{|c|c|c|c|c|c|}
\hline Corridor Number & Corridor Length(in km) & Corridor Density $\left(\mathrm{in} \mathrm{km} / \mathrm{km}^{-2}\right)$ & $\alpha$ Index & $\beta$ Index & $\gamma$ Index \\
\hline 78 & 2232.99 & 0.044 & 0.422 & 1.773 & 0.619 \\
\hline
\end{tabular}

Table 5. Source interaction matrix $(\mathrm{G})$ based on the gravity model.

\begin{tabular}{|c|c|c|c|c|c|c|c|c|c|c|c|c|c|}
\hline No. of sources & 1 & 2 & 3 & 4 & 5 & 6 & 7 & 8 & 9 & 10 & 11 & 12 & 13 \\
\hline 1 & 0 & 281 & 18 & 11 & 338 & 63 & 11 & 5 & 5 & 4 & 3 & 3 & 3 \\
\hline 2 & & 0 & 63 & 29 & 1092 & 45 & 10 & 9 & 4 & 4 & 4 & 2 & 4 \\
\hline 3 & & & 0 & 111 & 620 & 10 & 5 & 14 & 2 & 3 & 9 & 3 & 8 \\
\hline 4 & & & & 0 & 244 & 8 & 3 & 28 & 3 & 4 & 10 & 4 & 9 \\
\hline 5 & & & & & 0 & 288 & 38 & 45 & 14 & 14 & 24 & 10 & 20 \\
\hline 6 & & & & & & 0 & 59 & 4 & 10 & 10 & 5 & 6 & 4 \\
\hline 7 & & & & & & & 0 & 4 & 11 & 9 & 6 & 5 & 3 \\
\hline 8 & & & & & & & 0 & 7 & 14 & 115 & 14 & 88 \\
\hline 9 & & & & & & & & & & 0 & 18 & 23 & 11 \\
\hline 10 & & & & & & & & & & & 0 & 55 & 385 \\
\hline 11 & & & & & & & & & & & & 0 & 22 \\
\hline 12 & & & & & & & & & & & & 0 \\
\hline 13
\end{tabular}




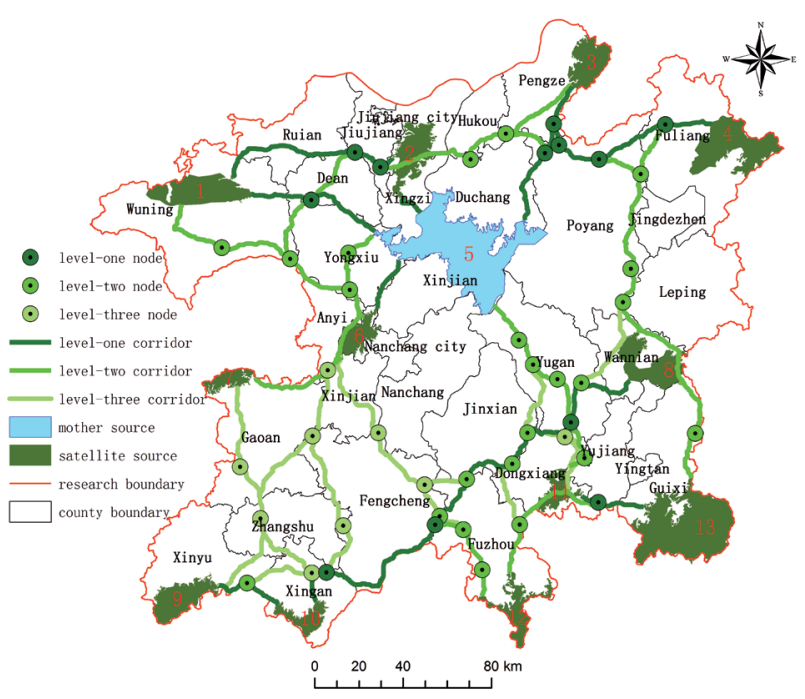

Fig. 4. The proposed hierarchical ecological network.

\section{Identification of Breaking Points}

In this paper, 63 critical breaking points were identified through overlaying the linear infrastructure network (main railways, highways, and stated roads) over the corridors (Fig. 5). The gained results indicated that they are distributed mainly on the railways of Beijing Kowloon, Shanghai Kun, and Wan Gan, and highways of Fu Yin, Ji Guang, Hang Rui, and Shanghai Kun. Due to the high density, the breaking points caused by state roads are much more relevant than those caused by railways and highways.

\section{Discussion}

Constructing an ecological network connecting large patches on a regional scale is conceived as an appealing strategy to conserve biodiversity and keep sustainable development in the urbanization context. In this study, we combined the least-cost path model, network structure analysis, and gravity model to construct a hierarchical ecological network for the Poyang Lake Eco-Economic Region in China. Accordingly, we demonstrated how

Table 6. Classification criteria of ecological nodes.

\begin{tabular}{|c|c|}
\hline Node Type & Classification Criteria \\
\hline $\begin{array}{c}\text { Level-one } \\
\text { ecological nodes }\end{array}$ & $\begin{array}{c}\text { Intersections of level-one ecological } \\
\text { corridors; intersections of level-one } \\
\text { ecological corridors and level-two } \\
\text { ecological corridors }\end{array}$ \\
\hline $\begin{array}{c}\text { Level-two } \\
\text { ecological nodes }\end{array}$ & $\begin{array}{c}\text { Intersections of corridors except the } \\
\text { ones defined as level-one or level-three } \\
\text { ecological nodes; important turning-point } \\
\text { of level-two ecological corridors }\end{array}$ \\
\hline $\begin{array}{c}\text { Level-three } \\
\text { ecological nodes }\end{array}$ & $\begin{array}{c}\text { Intersections of level-three ecological } \\
\text { corridors; important turning-point of } \\
\text { level-three ecological corridors }\end{array}$ \\
\hline
\end{tabular}

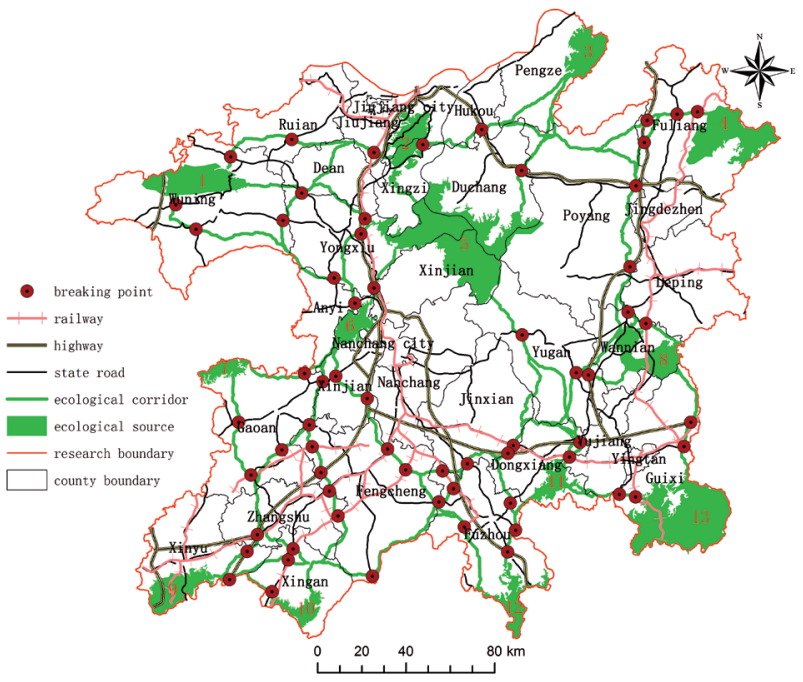

Fig. 5. Distribution map of breaking points.

the least-cost model can be improved to integrate more resistance factors in corridor simulation. Three resistance factors were taken into account, including land cover, slope, and human-induced pressure to comprehensively present the landscape characteristics, making sure the corridors were identified realistically. The $\alpha, \beta$, and $\gamma$ indices indicated that the proposed network has an adequate circuitry, complexity, and connectivity, and is favorable to matter cycle and energy flux [37]. More factors, such as the distribution of species, behavior features, and construction costs can also be incorporated into the least-cost model in ecological network development according to different design objectives.

Our results reveal how prioritization of the network elements can be quantitatively performed. Prioritization of the network elements is rather important, since most of the initiatives to develop ecological networks in the world just keep at the planning stage and have not been completely implemented because challenges often make implementation difficult $[19,29]$. The most common challenge is funding, which may force policymakers to implement only a few routes or sites $[19,40]$. We used the gravity model to prioritize the proposed network elements and we illustrated the priority results using a hierarchical ecological network. The hierarchical ecological network is composed of ecological sources at two priority levels, and ecological corridors and nodes at three priority levels. The elements with higher priority levels should receive more protection in future land-use. Besides, elements with higher priorities should be chosen to develop first when constructing a network with limited funds.

The prioritization results also indicated that the spatial distribution of the ecological nodes and corridors is rather uneven across the landscape. The nodes and corridors of higher priority always concentrate in the north of the study area, while most of the nodes and corridors of lower priority are located in the southern area. It could be speculated that the connection between south and north is rather weak. The three cost surfaces were added to the 
network to analyze the cause. Results showed that most of the northern area is composed of forested mountains, whereas most of the south - especially the southwest - are flat farmlands. On the one hand we found that land in the south is more likely to be converted to built-up areas than that in the north due to a lower cost. On the other hand, we demonstrated that the network developed in this way could reflect the real landscape characteristics comprehensively. In this sense, we suggested to management that more efforts should be made to restrict the uncontrolled urban expansion in the south and strengthen the relationship between the southern and northern areas.

The breaking points identified in the study illustrated how the linear transport infrastructures can fragment the landscape. Most of the breaking points concentrate in the southwest, corresponding to the terrain and land use pattern. These identified breaking points could be viewed as possible construction locations of underpasses, tunnels, and platform bridges $[23,41]$. Suitable choice varies from case to case. Analysis at finer-scales should be made to get more accurate information (position, slope, environment, and others) for decision- making. In the future, a suggested more feasible way is to emphasize ecological connectivity during infrastructure planning [42].

There are still several limitations to this study. First, the resistance values and weights of the cost surfaces were assigned through bibliographical review and expert consultation, and no dispersal behavior features of focal species were considered because of the lack of precise data. The values should be further tested and validated to help planners find more different corridors and decrease uncertainties $[6,22,28]$. Secondly, the proposed ecological network focuses on core areas and ecological corridors as the basic network elements. Buffer areas are not considered in this study due to difficulties with the identification of buffer zones, as they are site-dependent. Lastly, the proposed ecological network was designed on a regional level, which should be complemented with superregional, sub-regional and local scale ones, forming multiple-scale ecological networks. The reason is that landscape connectivity manifests itself in a multi-scale format depending on what species or functional groups are sensitive to the fragmentation of the selected habitats [29]. The development of ecological networks in a multi-scale format will be one of the aims of future research.

\section{Conclusions}

It is highly recommended to address the urgent need for new methods to establish sustainable and effective ways to protect biodiversity in China. Constructing an ecological network connecting large patches on a regional scale is defined as an appealing strategy, which can effectively alleviate the problem of habitat fragmentation, but it has been hardly ever discussed in China until the past decade. In this study, we demonstrated the effectiveness of an integrated methodology for regional ecological network planning by applying it to Poyang Lake Eco-Economic
Region in China. The integrated methodology is a combination of improved least-cost path model, network structure analysis, and gravity model. A hierarchical ecological network possesses an adequate circuitry and complexity, and then connectivity was proposed. The results of our study can present significant references to decision-making in both land-use management and network implementation. The proposed methodology is applicable to other regions.

\section{Acknowledgements}

The Natural Science Foundation of China (No. 41561043 and 41161031) funded this research. The authors are grateful to Haifeng Li from Jiangxi Agricultural University for valuable comments and linguistic checking. The authors greatly appreciate the thorough review and valuable comments of the anonymous reviewer that helped improve this manuscript.

\section{References}

1. CAFARO P. Three ways to think about the sixth mass extinction. Biol. Conserv. 192, 387, 2015.

2. BARNOSKY A.D., MATZKE N., TOMIYA S., WOGAN G.O., SWARTZ B., QUENTAL T.B., MARSHALL C., MCGUIRE J.L., LINDASEY E.L., MAGUIRE K.C., MERSEY B., FERRER E.A. Has the Earth's sixth mass extinction already arrived? Nature. 471 (7336), 51, 2011.

3. KRAUSS J., BOMMARCO R., GUARDIOLA M., HEIKKINEN R.K., HELM A., KUUSSAARI M., LINDBORG R., ÖCKINGER E., PÄRTEL M., PINO J., PÖYRY J., RAATIKAINEN K.M., SANG A., STEFANESCU C., TEDER T., ZOBEL M., STEFFANDEWENTER I. Habitat fragmentation causes immediate and time-delayed biodiversity loss at different trophic levels. Ecol. Lett. 13 (5), 597, 2010.

4. FAHRIG L. Rethinking patch size and isolation effects: the habitat amount hypothesis. J. Biogeogr. 40 (9), 1649, 2013.

5. VIZZARI M., SIGURA M. Landscape sequences along the urban-rural-natural gradient: A novel geospatial approach for identification and analysis. Landsc. Urban Plan. 140, 42, 2015.

6. RAYFIELD B., FORTIN M.J., FALL A. Connectivity for conservation: A framework to classify network measures. Ecology. 92(4), 847, 2011.

7. GARCÍA-FECED C., SAURA S., ELENA-ROSSELLÓ R. Improving landscape connectivity in forest districts: a two-stage process for prioritizing agricultural patches for reforestation. Forest Ecol. Manag. 261 (1), 154, 2011.

8. THÉAU J., BERNIER A., FOURNIER R.A. An evaluation framework based on sustainability-related indicators for the comparison of conceptual approaches for ecological networks. Ecol. Indic. 52, 444, 2015.

9. IGNATIEVA M., STEWART G.H., MEURK C. Planning and design of ecological networks in urban areas. Landsc. Ecol. Eng. 7(1), 17, 2011.

10. PRYKE J.S., SAMWAYS M.J. Ecological networks act as extensions of protected areas for arthropod biodiversity conservation. J. Appl. Ecol. 49 (3), 591, 2012. 
11. MOSSMAN H.L., PANTER C.J., DOLMAN P.M. Modelling biodiversity distribution in agricultural landscapes to support ecological network planning. Landsc. Urban Plan. 141, 59, 2015.

12. HOCTOR T.S., CARR M.H., ZWICK P.D. Identifying a linked reserve system using a regional landscape approach: the Florida ecological network. Conserv. Bio. 14 (4), 984, 2000.

13. FATH B.D., SCHARLER U.M., ULANOWICZ R.E., HANNON B. Ecological network analysis: network construction. Ecol. Model. 208 (1), 49, 2007.

14. DE MONTIS A., CASCHILI S., MULAS M., MODICA G., GANCIU A., BARDI A., LEDDAA A., DESSENAC L., LAUDARID L., FICHERA C.R. Urban-rural ecological networks for landscape planning. Land Use Policy. 50, 312, 2016.

15. JONGMAN R.H.G. The context and concept of ecological networks. In Ecological Networks and Greenways Concept, Design and Implementation; Jongman, R., Pungetti, G., Eds., Cambridge University Press: Cambridge, UK, 7, 2004.

16. SAURA S., ESTREGUIL C., MOUTON C., RODRÍGUEZFREIRE M. Network analysis to assess landscape connectivity trends: application to European forests (19902000). Ecol. Indic. 11 (2), 407, 2011.

17. KONG F.H., YIN H.W., NAKAGOSHI N., ZONG Y.G. Urban green space network development for biodiversity conservation: Identification based on graph theory and gravity modeling. Landsc. Urban Plan. 95 (1), 16, 2010.

18. FU Q., SONG J., MAO F., WU Y.X., YAO H., TANG J.B. Evaluation and construction of wetland ecological network in Qingdao City. Acta Ecol. Sin. 32 (12), 3670, 2012.

19. TENG M.J., WU C.G., ZHOU Z.X., LORD E., ZHEN Z.M. Multipurpose greenway planning for changing cities: A framework integrating priorities and a least-cost path model. Landsc. Urban Plan. 1 (1), 103, 2011.

20. LIU G.Y., YANG Z.F., CHEN B., ZHANG L.X., ZHANG Y., SU M.R. An ecological network perspective in improving reserve design and connectivity: a case study of Wuyishan Nature Reserve in China. Ecol. Model. 306, 185, 2015.

21. HEPCAN Ş., HEPCAN C..C., BOUWMA I.M., JONGMAN R.H., ÖZKAN M.B. Ecological networks as a new approach for nature conservation in Turkey: a case study of Izmir Province. Landsc. Urban Plan. 90 (3), 143, 2009.

22. SAWYER S.C., EPPS C.W., BRASHARES J.S. Placing linkages among fragmented habitats: do least-cost models reflect how animals use landscapes? J. Appl. Ecol. 48 (3), 668, 2011.

23. HUANG P.J., LIU Y.F. An integrated method to analyze forest ecological networks for urban sustainable development: a case study of Wuhan in central China. Pol. J. Environ. Stud. 23 (4), 1175, 2014.

24. MOILANEN A., HANSKI I. On the use of connectivity measures in spatial ecology. Oikos. 95 (1), 147, 2001.

25. HARGROVE W.W., HOFFMAN F.M., EFROYMSON R.A. A practical map-analysis tool for detecting potential dispersal corridors. Landsc. Ecol. 20 (4), 361, 2005.

26. RAYFIELD B., FORTIN M.J., FALL A. The sensitivity of least-cost habitat graphs to relative cost surface values. Landsc. Ecol. 25 (4), 519, 2010.

27. LI H.L., LI D.H., LI T., QIAO Q., YANG J., ZHANG H.M. Application of least-cost path model to identify a giant panda dispersal corridor network after the Wenchuan earthquakecase study of Wolong Nature Reserve in China. Ecol. Model. 221 (6), 944, 2010.

28. TENG M.J., ZHOU Z.X., WANG P.C., XIAO W.F., WU C.G., LORD E. Geotechnology-Based Modeling to Optimize Conservation of Forest Network in Urban Area. Enviro. Manag. 57 (3), 601, 2016.

29. GURRUTXAGA M., LOZANO P. J., DEL BARRIO G. GIS-based approach for incorporating the connectivity of ecological networks into regional planning. J. Nat. Conserv. 18 (4), 318, 2010.

30. GURRUTXAGA M., RUBIO L., SAURA S. Key connectors in protected forest area networks and the impact of highways: A transnational case study from the Cantabrian Range to the Western Alps (SW Europe). Landsc. Urban Plan. 101 (4), 310, 2011.

31. XIE H.L., WANG P., HUANG H.S. Ecological risk assessment of land use change in the Poyang Lake ecoeconomic zone China. Int. J. Environ. Res. Public Health. 10 (1), 328, 2013.

32. CHEN W.B., CARSJENS G.J., ZHAO L.H., LI H.F. A Spatial Optimization Model for Sustainable Land Use at Regional Level in China: A Case Study for Poyang Lake Region. Sustainability. 7 (1), 35, 2014.

33. ADRIAENSEN F., CHARDON J.P., DE BLUST G., SWINNEN E., VILLALBA S., GULINCK H., MATTHYSEN E. The application of 'least-cost' modeling as a functional landscape model. Landsc. Urban Plan. 64 (4), 233, 2003.

34. BROST B.M., BEIER P. Use of land facets to design linkages for climate change. Ecol. Appl. 22 (1), 87, 2012.

35. CHEN L.D., FU B.J., ZHAO W.W. Source-sink landscape theory and its ecological significance. Acta Ecol. Sin. 26 (5), 1444,2006

36. COOK E.A. Landscape structure indices for assessing urban ecological networks. Landsc. Urban Plan. 58(2), 269, 2002.

37. LI H.F., CHEN W.B., HE W. Planning of Green Space Ecological Network in Urban Areas: An Example of Nanchang China. Int. J. Environ. Res. Public Health. 12 (10), 12889, 2015.

38. LINEHAN J., GROSS M., FINN J. Greenway planning: developing a landscape ecological network approach. Landsc. Urban Plan. 33 (1), 179, 1995.

39. RUDD H., VALA J., SCHAEFER V. Importance of backyard habitat in a comprehensive biodiversity conservation strategy, a connectivity analysis of urban green spaces. Restor. Ecol. 10 (2), 368, 2002.

40. PALMISANO G.O., GOVINDAN K., LOISI R.V., SASSO P.D., ROMAR. Greenways for rural sustainable development: An integration between geographic information systems and group analytic hierarchy process. Land Use Policy. 50, 429, 2016.

41. TAYLOR B.D., GOLDINGAY R.L. Roads and wildlife: impacts, mitigation and implications for wildlife management in Australia. Wildlif. Res. 37, 320, 2010.

42. LORO M., ORTEGA E., ARCE R.M., GENELETTI D. Ecological connectivity analysis to reduce the barrier effect of roads. An innovative graph-theory approach to define wildlife corridors with multiple paths and without bottlenecks. Landsc. Urban Plan. 139, 149, 2015. 